\title{
Experimental swainsonine poisoning in goats ingesting Ipomoea sericophylla and Ipomoea riedelii (Convolvulaceae) ${ }^{1}$
}

\author{
Rossemberg C. Barbosa ${ }^{2}$, Franklin Riet-Correa ${ }^{3 *}$, Everton F. Lima ${ }^{3}$, Rosane M.T. \\ Medeiros $^{3}$, Karla M.R. Guedes ${ }^{3}$, Dale R. Gardner ${ }^{4}$, Russell J. Molyneux ${ }^{5}$ and \\ Lúcio E.H. de Melo ${ }^{6}$
}

\begin{abstract}
Barbosa R.C., Riet-Correa F., Lima E.F., Medeiros R.M.T., Guedes K.M.R, Gardner D.R., Molyneux R.J. \& Melo L.E.H. 2007. Experimental swainsonine poisoning in goats ingesting Ipomoea sericophylla and Ipomoea riedelii (Convolvulaceae). Pesquisa Veterinária Brasileira 27(10):409-414. Hospital Veterinário, CSTR, Universidade Federal de Campina Grande. Campus de Patos, 58700-000 Patos, Paraíba, Brazil. E-mail: franklin.riet@pq.cnpq.br

Ipomoea sericophylla and Ipomoea riedelii cause a glycoprotein storage disease in goats. This paper reports the experimental poisoning in goats by dried I. sericophylla and I. riedelii containing $0.05 \%$ and $0.01 \%$ swainsonine, respectively. Three groups with four animals each were used. Group 1 received daily doses of $2 \mathrm{~g} / \mathrm{kg}$ body weight (bw) of dried I. sericophylla (150mg of swainsonine $/ \mathrm{kg}$ ). Goats from this group had clinical signs 36-38 days after the start of ingestion. Group 2 received dried I. riedelii daily doses of $2 \mathrm{~g} / \mathrm{kg}$ of I. riedelii (30 $\mathrm{mg}$ of swainsonine $/ \mathrm{kg}$ ) for 70 days. No clinical signs were observed, therefore the swainsonine dose was increased to $60 \mathrm{mg} / \mathrm{kg}$ for another 70 days. Goats from Group 2 had clinical signs 26-65 days after increase in swainsonine dose to $60 \mathrm{mg} / \mathrm{kg}$. Group 3 was used as control. In these experiments the minimum toxic dose was $60 \mathrm{mg} / \mathrm{kg}$ which represents $0.0004 \%$ of the dry matter in goats ingesting $1.5 \%$ bw of the dry matter. For goats ingesting $2 \%-2.5 \%$ bw of dry matter this dose would be $0.00024 \%-0.0003 \%$ of the dry matter. After the end of the experiment two goats were euthanized and another six were observed for recovery of clinical signs. Four goats that continued to consume swainsonine containing plant for 39-89 days after the first clinical signs had non reversible signs, while two goats that ingested the plant for only 15 and 20 days after the first clinical signs recovered completely. These and previous results indicate that irreversible lesions due to neuronal loss occur in goats that continue to ingest the plants for about 30 days after the first clinical signs. Clinical signs and histological lesions were similar to those reported previously for goats poisoned by swainsonine containing plants. No significant alterations were found in packed cell volume, red and white blood cell counts, hemoglobin and mean corpuscular hemoglobin concentrations, mean corpuscular volume, and serum levels of glucose, total protein, and albumin, and the serum activities of gamma glutamyl transferase and aspartate aminotransferase. Swainsonine concentration of $0.05 \%$ in I. sericophylla and $0.01 \%$ in I. riedelii are different from samples of these plants used in previous experiments, which contained $0.14 \%$ and $0.5 \%$ swainsonine, respectively, demonstrating a wide variation in the toxicity of different samples.
\end{abstract}

INDEX TERMS: Poisonous plants, plant poisoning, lysosomal storage disease, swainsonine, goats, Ipomoea sericophylla, Ipomoea riedelii.

\footnotetext{
${ }^{1}$ Received on May 7, 2007.

Accepted for publication on June 19, 2007.

${ }^{2}$ Programa de Pós-Graduação em Ciência Veterinária, Universidade Federal Rural de Pernambuco, Recife, PE 52171-900, Brazil.

${ }^{3}$ Hospital Veterinário, CSTR, Universidade Federal de Campina Grande, Patos, PB 58700-000, Brazil. "Corresponding author: franklin.riet@pq.cnpq.br
}

\footnotetext{
${ }^{4}$ USDA/ARS Poisonous Plants Research Laboratory, 1150 East 1400 North, Logan, UT 84341, USA.

${ }^{5}$ USDA/ARS Western Regional Research Laboratory, 800 Buchanan Street, Albany, CA 94710, USA.

${ }^{6}$ Faculdade de Veterinária, Universidade Federal Rural de Pernambuco, Recife, PE 52171-900, Brazil.
} 
RESUMO-- [Intoxicação experimental por swainsonina em caprinos ingerindo Ipomoea sericophylla e Ipomoea riedelii.] Ipomoea sericophylla e Ipomoea riedelii causam uma doença de armazenamento de glicoproteínas em caprinos. Este trabalho relata a intoxicação experimental em caprinos por $I$. sericophylla e I. riedelii contendo $0,05 \%$ e $0,01 \%$ de swainsonina, respectivamente. Foram utilizados três grupos de quatro animais. O Grupo 1 recebeu doses diárias de $2 \mathrm{~g} / \mathrm{kg}$ peso vivo (pv) de $I$. sericophylla dessecada (150mg de swainsonina $/ \mathrm{kg}$ ). Os caprinos deste grupo apresentaram sinais clínicos 36-38 dias após o início da ingestão. $O$ Grupo 2 ingeriu diariamente $2 \mathrm{~g} / \mathrm{kg}$ de I. riedelii dessecada (30mg de swainsonina/ $/ \mathrm{kg}$ ) por 70 dias. Como não foram observados sinais clínicos a dose de suainsonina foi aumentada para $60 \mathrm{mg} / \mathrm{kg}$ por outros 70 dias. Os caprinos do Grupo 2 apresentaram sinais clínicos 26-65 dias após o aumento da dose de swainsonina para $60 \mathrm{mg} / \mathrm{kg}$. O Grupo 3 foi utilizado como controle. Neste experimento, a menor dose tóxica de swainsonina foi de $60 \mathrm{mg} / \mathrm{kg}$, que representa $0,0004 \%$ da matéria seca, em caprinos ingerindo $1,5 \%$ pv de matéria seca. Para caprinos ingerindo $2 \%-2,5 \% \mathrm{pv}$ de matéria seca essa dose corresponderia a $0,00024 \%-0,0003 \%$ da matéria seca. Após o final do experimento dois caprinos foram eutanasiados e outros seis foram observados para conferir a recuperação dos sinais clínicos. Quatro caprinos que continuaram ingerindo as plantas contendo suainsonina por 39-89 dias após os primeiros sinais clínicos permaneceram com sinais clínicos irreversíveis, enquanto que dois caprinos que ingeriram as plantas por 15 e 20 dias após os primeiros sinais clínicos se recuperaram totalmente. Estes resultados e os de trabalhos anteriores sugerem que as lesões irreversíveis, devidas à perda neuronal, ocorrem quando os caprinos continuam ingerindo a planta por aproximadamente 30 dias após o início dos sinais clínicos. Os sinais clínicos e as lesões histológicas foram similares às descritas anteriormente em animais intoxicados por plantas contendo swainsonina. Não foram observadas alterações significantes no hematócrito, número de eritrócitos e leucócitos, hemoglobina, volume corpuscular médio, concentrações séricas de glicose, proteínas totais e albumina e nas atividades séricas de gama glutamiltransferase e aspartato aminotransferase. As concentrações de swainsonina de $0,05 \%$ em I. sericophylla e 0,01\% em I. riedelii são diferentes de amostras de essas plantas utilizadas em experimentos prévios, que continham $0.14 \%$ e $0,5 \%$ de swainsonina, respectivamente, demonstrando uma marcada variação entre amostras.

TERMOS DE INDEXAÇÃO: Plantas tóxicas, intoxicação por planta, doenças do armazenamento lisossomal, swainsonina, caprinos, Ipomoea sericophylla, Ipomoea riedelii.

\section{INTRODUCTION}

Ipomoea sericophylla (Fig.1) and Ipomoea riedelii (Fig.2) contain swainsonine and cause glycoprotein storage disease in goats in the semiarid regions of Paraíba. (Barbosa et al. 2006). Other swainsonine containing plants in Brazil are Sida carpinifolia (Colodel et al. 2002b), Ipomoea carnea subsp. fistulosa (Haraguchi et al. 2003) and Turbina cordata (Dantas et al. 2007). S. carpinifolia causes intoxication in goats (Driemeier et al. 2000, Colodel et al. 2002a) horses (Loretti et al. 2003), sheep

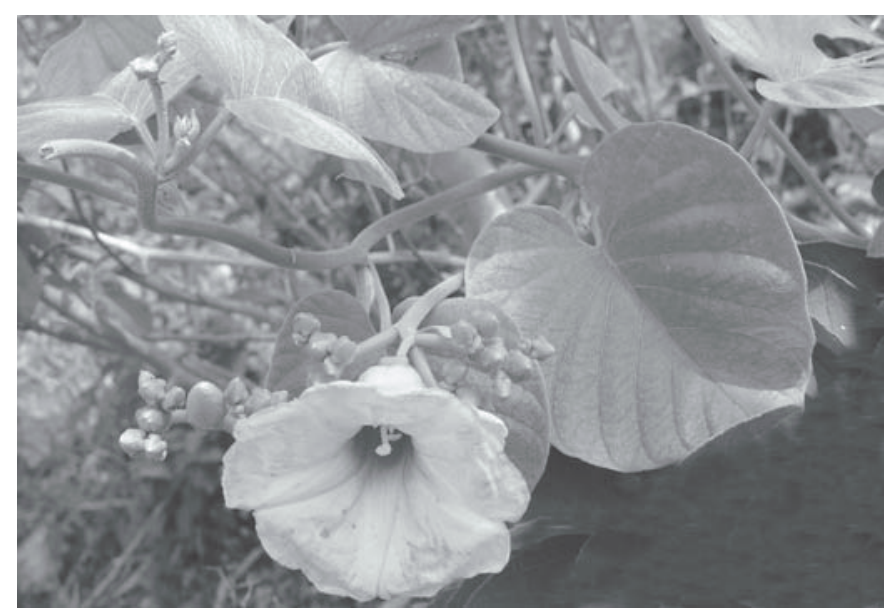

Fig.1. Ipomoea sericophylla, municipality of São Sebastião de Umbuzeiro, Paraíba, Brazil.

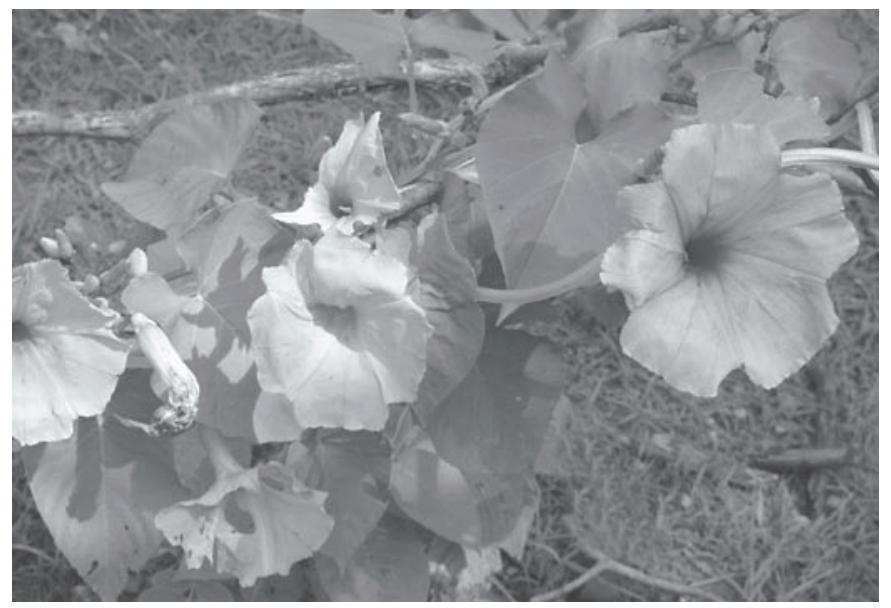

Fig.2. Ipomoea riedelii, municipality of Zabelé, Paraíba, Brazil.

(Seitz et al. 2005) and cattle (Barros et al. 2006). I. carnea subsp. fistulosa is toxic for goats (Tokarnia et al. 1960, Armien et al. 2007, Riet-Correa et al. 2003), cattle and sheep (Tokarnia et al. 1960) and Turbina cordata in goats, cattle (Dantas et al. 2007) and horses (F. Riet-Correa \& A.F.M. Dantas, unpublished data). The objective of the research reported here was to study the toxicity of swainsonine contained in I. sericophylla and $I$. riedelii in goats as a descriptive comparison of the toxicity of these two species of Ipomoea with other swainsonine containing plants, and to evaluate the reversibility of the clinical signs in affected goats.

\section{MATERIALS AND METHODS}

Samples of the plants used in the experiments were sent to the Empresa Pernambucana de Pesquisa Agropecuária, Recife, state of Pernambuco, Brazil, for botanical identification.

Plants fed to goats were collected during March 2003, from the municipalities of Zabelé (I. riedelii) and São Sebastião de Umbuzeiro (I. sericophylla). After collection the plants were spread on the ground and dried at ambient temperature in the shade.

A subsample of the plants given to the experimental animals was analyzed for swainsonine and calystegines. In brief, duplicate samples 
$(100 \mathrm{mg})$ of the air-dried plant material were extracted and the swainsonine isolated by ion-exchange resin. The final aqueous extract was then analyzed by liquid chromatography-mass spectrometry. The presence of swainsonine was verified using gas chromatography-mass spectrometry after a portion of the aqueous extract was dried and the residue derivatized by addition of $\mathrm{N}, \mathrm{O}$-bis(trimethylsilyl)trifluoroacetamide (BSTFA) and pyridine to convert swainsonine to its timethylsilyl ether derivative. Calystegines were analyzed by gas chromatography-mass spectrometry by the method of Molyneux et al. (1995). Dried, ground leaves (1g) were extracted with methanol (MeOH) for 16 hours in a Soxhlet apparatus, and the alkaloidal fraction was purified by ionexchange chromatography on a $5 \times 0.5 \mathrm{~cm}$ column of Dowex $50 \mathrm{WX} 8\left(\mathrm{NH}_{4}{ }^{+}\right.$form). The $0.5 \%$ aqueous ammonium hydroxide eluate was evaporated to dryness to give the basic fraction, containing any alkaloids and basic amino acids. Portions of this material were used for gas chromatography-mass spectometric (GC-MS) analysis of the trimethylsilyl (TMSi) derivatives, prepared by treatment with $\mathrm{N}$-methyl- $\mathrm{N}$-trimethylsilyltrifluoroacetamide (MSTFA) in pyridine at $60^{\circ} \mathrm{C}$ for 1 hour. Analyses were performed on a HewlettPackard 5890 Series II instrument equipped with a 5971 mass-selective detector operating at $70 \mathrm{eV}$, an oncolumn injector, and a $60 \mathrm{~m} \times 0.32 \mathrm{~mm}$ id SE30 fused Si column. The column was temperature programmed from $120^{\circ} \mathrm{C}$ to $300^{\circ} \mathrm{C}$ at $10^{\circ} \mathrm{C} / \mathrm{min}$.

Twelve goats, males and females, from the Moxotó breed, 4 to 20-month-old were divided into three groups. Group 1 (Goats 1-4) was fed, for 77-127 days, with a ground commercial goat concentrate feed mixed with $2 \mathrm{~g}$ per $\mathrm{kg}$ body weight $(\mathrm{g} / \mathrm{kg})$ of dried Ipomoea serycophylla. Group 2 (Goats $4-8$ ) received commercial feed mixed with $2 \mathrm{~g} / \mathrm{kg}$ of dried Ipomoea riedelii. After 70 days of experiment the amount of dry Ipomoea riedelii was increased to $4 \mathrm{~g} / \mathrm{kg}$; and the plant was given at this dosage for an additional 70 days period. Group 3 (Goats 9-12) was fed concentrated goat feed in an amount equivalent to $1.5 \%$ body weight, and Cynodon dactylon (Tifton) hay ad libitum. The goats were weighed weekly to calculate the plant doses.

During the experiment all animals were examined daily by performing a detailed nervous system examination, including the head raising test and the stand up test (Barbosa et al. 2005). Cardiac and respiratory rates, body temperature and ruminal movements were determined weekly, during the early morning period.

Blood samples were collected every 15 days. Blood samples for the determination of hematological values were collected with $1 \mathrm{mg} /$ $\mathrm{ml}$ of ethylenediamine tetra-acetic acid (EDTA). The packed cell volume (PCV) was measured by standard microhematocrit method.
The red blood cell count (RBC) and total white blood cells count (WBC) were determined using the Neubauer chamber method. The hemoglobin $(\mathrm{HB})$ concentration was determined colorimetrically after its conversion to methemoglobin. Mean corpuscular volume (MCV), and mean corpuscular hemoglobin concentration (MCHC) were calculated as described by Ferreira Neto et al. (1981). Blood smears stained with May-Grunwald Giemsa were used for differential leukocyte count (Matos \& Matos 1995). Six mL of blood were used to analyze serum biochemistry. The serum values of glucose, total protein, and albumin, and the serum activities of gamma glutamyl transferase (GGT) and aspartate aminotransferase (AST) were determined using commercial reagents (Labtest, Belo Horizonte, Minas Gerais, Brazil), and analyzed in an automatic biochemical analyzer (Bioplus 2000). Globulin values were obtained by the difference between total protein and albumin.

Goats 3 and 7 were euthanized and necropsied 1 day after the end of the dosing period. The others were observed daily for regression of clinical signs. After fixation, the central nervous system (CNS) was sectioned in 4-5mm transverse sections. Transverse sections taken from the cervical, thoracic and lumbar spinal cord, medulla oblongata, pons, rostral colliculi, thalamus, basal nuclei and internal capsule, cortex, cerebellar peduncles, and cerebellum were examined histologically. Longitudinal sections of the spinal cord were also studied. Samples of liver, kidney, lung, lymph nodes, spleen, thyroid, adrenal, stomach, small and large intestine, cardiac, skeletal muscles and peripheral nerves were also fixed in $10 \%$ neutral formalin. All tissues were embedded in paraffin, sectioned at $6 \mu \mathrm{m}$, and stained with hematoxylin and eosin.

\section{RESULTS}

Voucher specimens of the plant collected in the municipality of Zabelé were identified as Ipomoea riedelii Meisn, Monteiro, Paraíba, № 66101 (IPA), and Ipomoea sericophylla Monteiro, Paraíba, No 66098 (IPA).

Chemical analysis of Ipomoea sericophylla and Ipomoea riedelii found swainsonine contents to be $0.05 \%$ and $0.01 \%$ (dry weight), respectively. No calystegines were detected in either of the plants. Calculations of the swainsonine daily doses in goats ingesting $I$. sericophylla and $I$. riedelii, the time of onset of clinical signs, the outcome of the poisoning and the weight gains of the experimental goats are presented in Table 1.

Table 1. Swainsonine daily doses in goats ingesting Ipomoea sericophylla and Ipomoea riedelii, onset of clinical signs, weigh gains and outcome of the poisoning

\begin{tabular}{|c|c|c|c|c|c|c|c|c|c|}
\hline Plant & $\begin{array}{c}\text { Goat } \\
\text { № }\end{array}$ & $\begin{array}{l}\text { Swainsonine } \\
\text { concentration } \\
\text { (dried plant) }\end{array}$ & $\begin{array}{l}\text { Amount of } \\
\text { concentrate } \\
\text { food (\% of } \\
\text { body weight) }\end{array}$ & $\begin{array}{l}\text { Concentration } \\
\text { of plant in the } \\
\text { concentrate } \\
\text { food }\end{array}$ & $\begin{array}{c}\text { Daily } \\
\text { swainsonine } \\
\text { dose }\end{array}$ & $\begin{array}{l}\text { Days of plant } \\
\text { consumption }\end{array}$ & $\begin{array}{l}\text { First clinical } \\
\text { signs (days) }\end{array}$ & $\begin{array}{l}\text { Weight } \\
\text { gains (kg) }\end{array}$ & $\begin{array}{l}\text { Outcome of } \\
\text { the poisonimg }\end{array}$ \\
\hline I. sericophylla & 1 & $0.05 \%$ & $1.5 \%$ & $20 \mathrm{~g} / \mathrm{kg}$ & $150 \mathrm{mg} / \mathrm{kg}$ & 77 & 38 & 0.9 & Permanent clinical signs \\
\hline I. sericophylla & 2 & $0.05 \%$ & $1.5 \%$ & $20 \mathrm{~g} / \mathrm{kg}$ & $150 \mathrm{mg} / \mathrm{kg}$ & 127 & 38 & -0.6 & Permanent clinical signs \\
\hline I. sericophylla & 3 & $0.05 \%$ & $1.5 \%$ & $20 \mathrm{~g} / \mathrm{kg}$ & $150 \mathrm{mg} / \mathrm{kg}$ & 127 & 38 & 0,7 & Euthanized on day 128 \\
\hline I. sericophylla & 4 & $0.05 \%$ & $1.5 \%$ & $20 \mathrm{~g} / \mathrm{kg}$ & $150 \mathrm{mg} / \mathrm{kg}$ & 75 & 36 & 1.7 & Permanent clinical signs \\
\hline I. riedelii & $5-8^{a}$ & $0.01 \%$ & $1.5 \%$ & $20 \mathrm{~g} / \mathrm{kg}$ & $30 \mathrm{mg} / \mathrm{kg}$ & 70 & $\begin{array}{l}\text { No clinical } \\
\text { signs in } \\
70 \text { days }\end{array}$ & & \\
\hline I. riedelii & $5^{b}$ & $0.01 \%$ & $1.5 \%$ & $40 \mathrm{~g} / \mathrm{kg}$ & $60 \mathrm{mg} / \mathrm{kg}$ & 70 & 20 & 0.9 & Recovered in 9 days \\
\hline I. riedelii & $6^{b}$ & $0.01 \%$ & $1.5 \%$ & $40 \mathrm{~g} / \mathrm{kg}$ & $60 \mathrm{mg} / \mathrm{kg}$ & 70 & 15 & 3.9 & Recovered in 6 days \\
\hline I. riedelii & $7^{b}$ & $0.01 \%$ & $1.5 \%$ & $40 \mathrm{~g} / \mathrm{kg}$ & $60 \mathrm{mg} / \mathrm{kg}$ & 70 & 57 & 6,5 & Euthanized on day 141 \\
\hline I. riedelii & $8^{b}$ & $0.01 \%$ & $1.5 \%$ & $40 \mathrm{~g} / \mathrm{kg}$ & $60 \mathrm{mg} / \mathrm{kg}$ & 70 & 29 & -1.6 & Permanent clinical signs \\
\hline
\end{tabular}

a First period. These goats were fed in two periods: one of 70 days without clinical signs followed by another period of 70 days.

b Second period. 
Goats 1 and 4 fed I. sericophylla for 77 and 75 days showed clinical signs after 38 and 36 days of ingestion, respectively. Goats 2 and 3 were fed I. sericophylla for a total of 127 days, with clinical signs starting on the $38^{\text {th }}$ day. Goat 3 was euthanized and necropsied 1 day after the end of administration $\left(129^{\text {th }}\right.$ day). One hundred days after the end of the plant administration Goats 1, 2 and 4 continued to show clinical signs, but they were of less intensity.

Goats fed Ipomoea riedelii (Group 2) showed no clinical signs after 70 days and therefore the dose of dry plant was increased from $2 \mathrm{~g} / \mathrm{kg}$ to $4 \mathrm{~g} / \mathrm{kg}$ bw for an additional 70 days period. Goat 5 showed clinical signs 120 days after the start of plant administration ( 50 days after the daily ingestion of $4 \mathrm{~g} / \mathrm{kg}$ ). On the $141^{\text {st }}$ day the plant administration was suspended and 9 days later $\left(150^{\text {th }}\right.$ day) the animal had completely recovered. Goat 6 showed clinical signs 135 days after the start of the experiment ( 65 days after the ingestion of $4 \mathrm{~g} / \mathrm{kg}$ ). On the $141^{\text {st }}$ day plant administration was suspended, and the animal fully recovered within 6 days. Goat 7 showed the first clinical signs 127 days after the start of the experiment (57 days after the ingestion of $4 \mathrm{~g} / \mathrm{kg}$ ). It was euthanized and necropsied on the $141^{\text {th }}$ day. Goat 8 presented the first clinical signs on day 99 after the start of feeding ( 29 days after the ingestion of $4 \mathrm{~g}$ / $\mathrm{kg}$ ), and was still eating the plant until the $140^{\text {th }}$ day. After the end of the administration clinical signs decreased, but did not completely resolve.

Clinical signs were similar in all affected animals. Initial signs of poisoning were depression, reduced food consumption, mild intention tremors, and incoordination when disturbed. On the stand up test, most affected goats took more time getting up than goats from the control group. Over the next 7-10 days the clinical signs became more pronounced with increased intention tremors, incoordination and falling when disturbed or frightened. Ataxia, hypermetria, wide-based stance, mainly in the hind legs, abnormal postural reactions, nystagmus, depressed tongue or lip tonus, and occasionally other signs of cranial nerve impairment were also observed. In Goats 1-5 and 8 severe intention tremors or falling were induced by raising the head of the animal for about 60 seconds and then suddenly releasing it (head raising test).

In all goats from the three groups serum levels of protein, albumin and glucose, serum activities of GGT and AST, and $\mathrm{PCV}, \mathrm{RBS}, \mathrm{WBC}, \mathrm{HB}, \mathrm{MCV}$ and MCHC values were within normal values during the whole experiment.

No gross lesions were observed in the two goats necropsied (Goat 3 and 7).

Upon histologic examination, Goat 3 had severe vacuolation of epithelial cells of the liver, pancreas, kidney and thyroids. The cerebellum Purkinje cells had moderate to accentuated vacuolation, with nuclear margination in some neurons. Moderate numbers of axonal spheroids were observed in the granular layer of the cerebellum. In the cerebellar white matter axonal spheroids were more frequent than in the granular layer. The cerebellar nuclei and some nuclei of Pons and Medulla oblongata had severe neuronal vacuolation and a moderate to accentuated number of axonal spheroids. Vacuolation of the perikaryon was observed in a

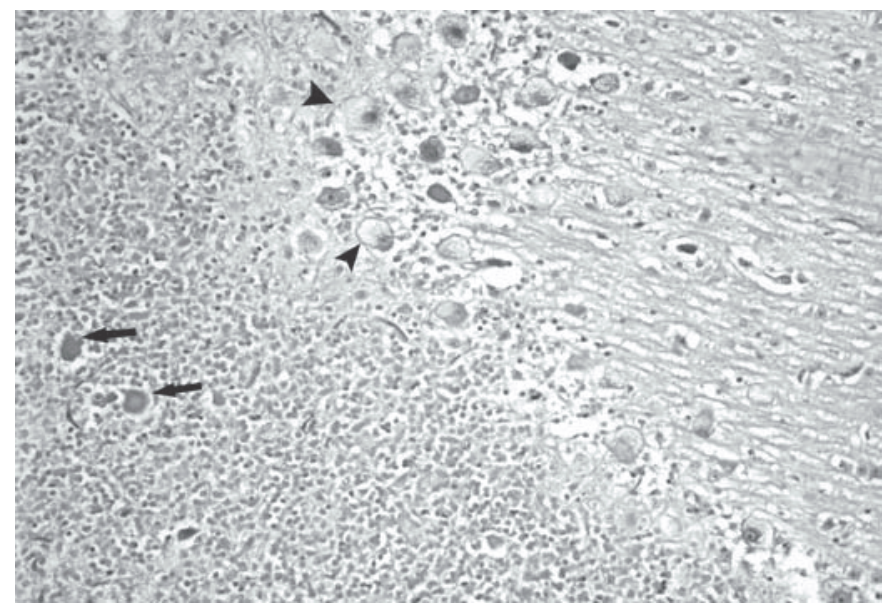

Fig.3. Cerebellum of Goat 7. Severe vacuolation is observed on Purkinje cells (arrow heads); few axonal spheroids are present in the granular layer (arrows). HE, obj.10x.

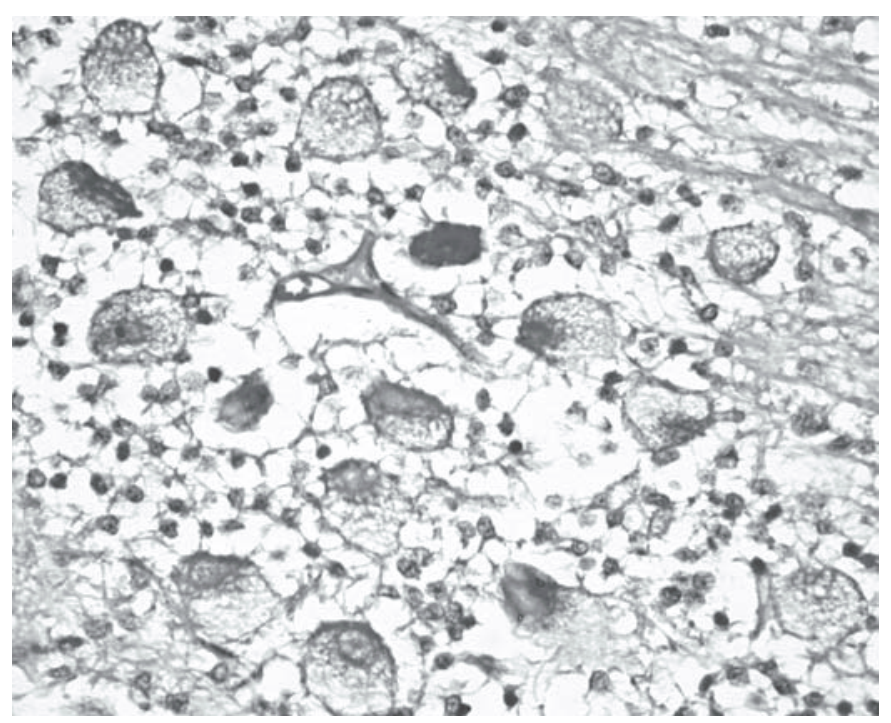

Fig.4. Cerebellum of Goat 7. Severe vacuolation is observed on Purkinje cells. HE, obj.20x.

few neurons of Thalamus and rostral culliculi. Moderate neuronal vacuolation and a few axonal spheroids were observed in the cervical, thoracic, and lumbar spinal cord.

Histologic lesions in Goat 7 were similar, but with lesser amounts of axonal spheroids. Neuronal vacuolation in the brain stem and cerebellar nuclei were less severe than in Goat 3 , but vacuolation in the Purkinje cells of the cerebellum and in neurons of the spinal cord were more severe (Fig.3 and 4).

\section{DISCUSSION}

The results of this experiment confirmed that Ipomoea sericophylla and Ipomoea riedelii are the cause of an acquired glycoprotein storage disease, as reported by Barbosa et al. (2005). The concentrations of swainsonine in the plants used here $(0.05 \%$ in I. sericophylla and $0.01 \%$ in I. redelii) were lower than the concentrations reported previously $(0.11 \%$ in $I$. sericophylla and $0.14 \%$ in I. riedelii) (Barbosa et al. 2005), 
indicating a wide variation in swainsonine content in both species, which corresponds to the variation in the frequency of the disease in field outbreaks (Barbosa et al. 2005). The swainsonine concentration in Turbina cordata has also been found to be quite variable (Dantas et al. 2007).

A threshold for toxicity is difficult to establish for swainsonine, but a conservative approach suggests that concentrations in excess than $0.001 \%$ of the poisonous plant are probably toxic (Molyneux et al. 1994). In the experiments reported here, the minimal toxic dose was $60 \mathrm{mg} / \mathrm{kg}$, which represents $0.0004 \%$ of the total dry matter (swainsonine containing plant plus any additional feed) in goats ingesting $1.5 \%$ body bw of dry matter. For goats ingesting $2 \%-2.5 \%$ bw of dry matter this dose will be $0.00024 \%-0.0003 \%$ swainsonine of the dry matter. The daily dose of $30 \mathrm{mg} / \mathrm{kg}$ of swainsonine did not cause clinical signs after 70 days. The absence of clinical signs in these goats and the occurrence of clinical signs 29-65 days after the increase of the dose to $60 \mathrm{mg} / \mathrm{kg}$ indicate that a dose of swainsonine at $30 \mathrm{mg} / \mathrm{kg}$ bw is not toxic (at least up to 70 days) but that swainsonine ingested at $60 \mathrm{mg} / \mathrm{kg}$ is toxic. A dose of swainsonine at $150 \mathrm{mg} / \mathrm{kg}$ caused clinical signs in 3638 days.

In previous experiments with Ipomoea spp. (Barbosa et al. 2005) and Turbina cordata (Dantas et al. 2007), goats were reported as ingesting fresh Ipomoea riedelii, containing $0.14 \%$ swainsonine, as the only food, had clinical signs 11 days after the daily ingestion of 95 and $115 \mathrm{~g} / \mathrm{kg}$ of plant $(26.6$ and $32.2 \mathrm{mg}$ swainsonine per $\mathrm{kg} \mathrm{bw}$ ), and died after 22 days of ingestion. In the same experiment, goats ingesting swainsonine from dry I. riedelii or I. sericophylla, at daily doses of 3.3 and $4.2 \mathrm{mg} /$ $\mathrm{kg}$, had clinical signs after 20-50 days of ingestion. In another experiment, goats ingesting Turbina cordata showed clinical signs 28 and 54 days after the mean daily ingestion of 3.1 and $2.7 \mathrm{mg}$ swainsonine/kg, respectively. In experiments with Astragalus lentiginosus, two groups of sheep were reported as ingesting an estimated daily doses of swainsonine of 1 and $1.5 \mathrm{mg} / \mathrm{kg}$, the a-mannosidase levels dropped after one day to $53 \pm 17 \mathrm{mM}$ and $39 \pm 12 \mathrm{mM}$, respectively. Since there were no differences in a-mannosidase activities in 12 experimental days, it was suggested that both doses were high enough to inhibited completely all serum a-mannosidase and that there is a dose threshold at which the enzyme is completely saturated (Stegelmeier et al. 1994).

Goats $1,2,4$ and 8 continued to consume the toxic plant for 39 to 89 days after the first clinical signs, and had non reversible signs. In contrast, Goats 5 and 6 that ingested the toxic plant for only 15 and 20 days after the first clinical signs recovered completely after being taken of treatment with $I$. riedelii. In previous experiments with swainsonine containing plants, goats that were still ingesting toxic plants for 20-38 days after the initial clinical signs recovered within 4-14 days after removal from the swainsonine containing plant (Barbosa et al. 2005); but one goat that continued ingesting the plant for 40 days after the start of clinical signs did not recover (Dantas et al. 2007). These results indicate that irreversible lesions due to neuronal loss occur in goats that continue ingesting the plants for about 30 days after the first clinical signs. If before 30 days the affected animals are removed from pastures invaded by swainsonine containing plants there is a good chance that they may fully recover. This ability to recover from the poisoning, if animals are not grazed for too long of periods on the swainsonine containing plants, is an important aspect to consider for the control of poisoning. Another point is that affected animals had developed an apparent craving for grazing swainsonine containing plants and will thus eat them in preference to other plants (Barbosa et al. 2005, Dantas et al. 2007). As a consequence, it might be necessary to cull goats identified as Ipomoea spp. eaters, as a means to prevent the development of feed preference in other goats.

Clinical signs and histologic lesions observed in the experimental animals were similar to those reported in poisoning by other swainsonine containing plants in Brazil (Tokarnia et al. 1960, Armien et al. 2007, Riet-Correa et al. 2003, Dantas et al. 2007). Serum levels of protein, albumin and glucose, serum activities of GGT and AST, and PCV, RBS, WBC, HB, MCV and $\mathrm{MCHC}$ values were within normal values. In an experiment with Astragalus mollisimus var. mollisimus in cattle, serum biochemistry and urinalysis had no alterations, except for hypoalbuminaemia, due probably to urinary protein loss associated with renal lesions, and low serum thyroid levels, especially $\mathrm{T}^{3}$, which were correlated with the doses of swainsonine (Stegelmeier et al. 1994).

Aknowledgements.- The authors thank Dr. M.B. Costa e Silva from the Federal Rural University of Pernambuco for the botanical identification of the plants. This project was financially supported by "Programa de Apoio a Núcleos de Excelência” (PRONEX, Grant № 001/04, CNPq, FAPESP, MCT), and by "Institutos do Milénio" (Grant № 420012/2005-2, CNPq).

\section{REFERENCES}

Armién A.G., Tokarnia C.H., Peixoto P.V. \& Frees K. 2007. Spontaneous and experimental glycoprotein storage disease of goats induced by Ipomoea carnea subsp fistulosa (Convolvulaceae). Vet. Pathol. 44:170-184.

Barbosa R.C., Riet-Correa F., Medeiros R.M.T., Lima E.F., Barros S.S., Gimeno J.E., Molyneux R.J. \& Gardner D.R. 2006. Intoxication by Ipomoea sericophylla and Ipomoea riedelii in goats in the state of Paraíba, Northeastern Brazil. Toxicon 47:371-379.

Barros C.S.L., Driemeier D., Dutra I. \& Lemos R.A.A. 2006. Doenças do sistema nervoso de bovinos. Coleção Vallée, São Paulo, p.107-109.

Colodel E.M., Driemeier D., Loretti A.P., Gimeno E.J., Traverso S.D., Seitz A.L. \& Zlotowski P. 2002a. Aspectos clínicos e patológicos da intoxicação por Sida carpinifolia (Malvaceae) em caprinos no Rio Grande do Sul. Pesq. Vet. Bras. 22(2):51-57.

Colodel E.M., Gardner D.R., Zlotowski P. \& Driemeier D. 2002b. Identification of swainsonine as a glycoside inhibitor responsible for Sida carpinifolia poisoning. Vet. Human Toxicol. 44(3):177-178.

Dantas A.F.M., Riet-Correa F., Gardner D.R., Medeiros R.M.T., Barros S.S., Anjos B.L. \& Lucena R.B. 2007. Swainsonine-induced lysosomal storage disease in goats caused by the ingestion of Turbina cordata in Northeastern Brazil. Toxicon 49:11-116.

Driemeier D., Colodel E.M., Gimeno J.E. \& Barros S.S. 2000. Lysosomal storage disease caused by Sida carpinifolia poisoning in goats. Vet. Pathol. 37:153159.

Ferreira Neto J.M., Viana E.S. \& Magalhães L.M., 1981. Patologia Clínica Veterinária. Rabelo, Belo Horizonte. 279p.

Haraguchi M., Gorniak S.L., Ikeda K., Minami H., Kato A., Watson A.A., Nash R., Molyneux R.J. \& Asano N. 2003. Alkaloidal components in the poisonous plant Ipomoea carnea (Convolvulaceae). J. Agric. Food Chem. 51:4995-5000. 
Loretti A.P., Colodel E.M., Gimeno E.J. \& Driemeier D. 2003. Lysossomal storage disease in Sida carpinifolia toxicosis: an induced mannosidosis in horses. Eq. Vet. J. 35(5):434-438.

Matos M.S. \& Matos P.F. 1995. Laboratório Clínico Médico Veterinário. 2ª ed. Editora Atheneu, São Paulo. 238p.

Molyneux R.J., James L.F., Ralphs M.H., Pfister J.A., Panter K.P. \& Nash R.J. 1994. Polyhydroxy alkaloids glycosidase inhibitors from poisonous plants of global distribution: analysis and identification, p.107-112. In: Colegate S.M. \& Dorling P.R. (ed.), Plant-Associated Toxins: agricultural, phytochemical and ecological aspects. CAB International, Wallingford, UK.

Molyneux R.J., McKenzie R.A., O’Sullivan B.M. \& Elbein A.D. 1995. Identification of the glycosidase inhibitors swainsonine and calystegine $\mathrm{B}_{2}$ in weir vine (Ipomoea sp. Q6 [aff. calobra]) and correlation with toxicity. J. Nat. Prod. 6:878-886.
Riet-Correa F., Tabosa I.M., Azevedo E.O., Medeiros R.M., Simões S.V.D., Dantas A.F., Alves C.J., Nobre V.M.T., Athayde A.C., Gomes A.A. \& Lima E.F. 2003. Doenças dos ruminantes e eqüinos no semi-árido da Paraíba. Semi-Árido em Foco 1:4-111.

Seitz A.L., Colodel E.M., Barros S.S. \& Driemeier D. 2005. Intoxicação experimental por Sida carpinifolia em ovinos. Pesq. Vet. Bras. 25:15-20.

Stegelmeier B.L., Ralphs M.H., Gardner D.R., Molyneux R.J. \& James L.F. 1994. Locoweed intoxication in range cattle and sheep: Serum a-mannosidase activity and clinicopathologic, p.501-506. In: Colegate L.M., Dorling P.R. (ed.), Plant-Associated Toxins: agricultural, phytochemical and ecological aspects. CABI Publishing, Wallingford, UK.

Tokarnia C.H., Döbereiner J. \& Canella C.F.C. 1960. Estudo experimental sobre a toxidez do "canudo" (Ipomoea fistulosa Mart.) em ruminantes. Arqs Inst. Biol. Animal, Rio de J., 3:57-71. 